\title{
Effectiveness of Role Play in Improving Speaking Skill
}

Binod Neupane

\begin{abstract}
This study was carried out to find out the effectiveness of role play technique in improving speaking skill in English. The population of the study was the grade X students of a public school from Lamjung district. The experimental group was taught through role play while the control class was taught through the traditional grammar based techniques. The total population of this study was 40 students who were enrolled in the academic year 2018/2019. The study was experimental approach. The tools applied in this research were observation sheet and speaking test. After 20 lessons of the teaching, the post-test of speaking was conducted in which the students in both groups were asked to answer. The results showed that there is a significant improvement in speaking skill of experimental group. It can be concluded that role play have significant effect on students'speaking skill.
\end{abstract}

Keywords: control ,experiment, role play, speaking ,technique

\section{Introduction}

One of the main goals of teaching English as a foreign language in Nepal is to make the students able to communicate in the target language. For the effective communication, students should be able to speak English fluently. To develop students' proficiency in speaking, different techniques of teaching have been recommended. In the speaking class, the students must be able to speak English. If the students have an inability to speak in English, they will face difficulty in expressing their ideas in classroom activities. Therefore, students must have ability to communicate and share their ideas, opinions and explanations in their classroom. Role play provides an opportunity to the students to express appropriate language functions correctly in the given roles and situation.

Due to more focus on paper pencil examination, i.e., reading and writing, the students of Secondary Education Examination (SEE) level are given less emphasis on communicative skills. The teachers follow the grammar based traditional techniques to develop communicative skills. It is found that the students who are able to write an essay on a given topic fail to communicate a simple idea fluently. So that, it is very significant to teach students some skills that they can use in the everyday interaction and role play can be an effective technique for this.

Richard (1985) defines role play as a drama-like classroom activities in which students take the roles of different participants in a situation, and, act out what might typically happen in that situation. For example, to practice how to express complains and apologies in a foreign language, students might have to role-play a situation in which a customer in a shop returns a faulty article to a salesperson. Doff (1992) states that in a role play, students imagine a role (e.g. a police officer, a shop assistant), a situation (e.g., buying food, planning a party) or both. Role play should be improvised; students decide exactly what to say as they go along. Situation, roles and useful expressions are the three parts in a role play.

Tompkins (2001) defines role play as it is one of the classroom teaching techniques that encourage 
students to participate actively in the process of learning English. Therefore, foreign language students practise the target language in context similar to real-life situations where stress and shyness are removed. Keneth (2008) states that role play can be defined as the type of students' behave in a certain context. In the field of managing, discrepancies in the identifying role that can be seen as role conflict which does not match for a person or by others role playing as a method of teaching which is the conscious practicing and discussion of the role in a group. While in the class, the difficulty can be briefly acted out so that the student can identify with the roles. Role play activities could be shown as the way student behaves in specific context and situation. The researcher defines the role playing technique as a methodology for teaching which is conscious representation and discussion of the role in a group. In the class a problem context is shortly acted out so that the students can cope with the character.

Chaney (1998) states that speaking ability is the process of sharing and building meaning while using verbal and non-verbal symbols, in different situations. Speaking is significant in both languages learning and teaching. For long time, students recall the activities and memorized the conversations but nowadays, they should study how to express themselves. They should follow social and cultural rules in any context.

The present study is only a part of an investigation project, which was conducted to study the effectiveness of role play in improving speaking skill of SEE level Nepalese students. In a speaking class, besides other oral activities like picture description, storytelling and quizzing, role play can be used to develop students' conservational skills. A role play technique not only makes the students fluent in speaking but also makes them creative and confident. As communication is not confined in one situation and a role play gives them the scope to play a series of different situational interactions in a real life situation.

\section{Review of Literature}

Role play is an effective technique to develop students' speaking skill as it provides ample opportunities to the students to take roles of different persons. Several studies have been carried out to find the different aspects of role play techniques in EFL classrooms. The review of some of them has been mentioned in this section.

Cornett (1999) shows that students improve fluency in language and oral interaction skills, beside the use of language of the body during face-to-face communication, when they are participated in role play techniques. Those techniques are especially fundamental for students learning a foreign language who may not often speak English at home because those students are eager to use the language and then improve their fluency and speaking with the chance to participate in role play. Role-play is simply required to play the other roles in the same way they think about how other roles may behave. As a result, role play can be clearly understood of many aspects like reactions, values, feelings, and attitudes of the person in the same.

Ments (1999) mentions a lot of areas where role play could be used. For testing linguistic ability, he said it could be done by devising scenes of everyday life, in particular those situations which make use of the vocabulary to be learnt, the students can be encouraged to use language in a free and interesting way. He also noticed that one is using language and other ways of communicating and for that reason learning 
became 'an integral part of the task.' About role-play Ments claimed that it expresses hidden feelings, student can discuss private issues and problems, enables students to empathize with others and understand their motivation.

Hedge (2000) states that a number of advantages have been claimed for role-play as a fluency activity if it is performed in pairs or groups rather than one group acting in front of the class. The students choose the role they want to play. Savignon (2003) conducts an important study on the improvement of interaction skills designed on a model of communicative competence including many basic characteristics. She defines communicative competence as the ability to function in a truly communicative setting- that is, in a dynamic exchange in which linguistic competence must adjust itself to the total informational input, both linguistic and paralinguistic, of one or more interlocutors.

Holt and Kysilka (2006) state that role play technique can be fun and lead to develop learning, these techniques can be used a student communication, they help EFL students to comprehend the importance of cooperation and to have an interest in learning. Liu and Ding (2009) used role-play technique to see how the students performed in groups when they were given a familiar situation to role play in. They also observed their language potency and how the errors can be corrected as well as how to give feedback to the learners for further improvement. Jannah (2011) states that role play is very important in teaching speaking because it gives students in opportunity to practice communicating in different social context and in different social roles.

Yuliana, Kristiawan and Suhartie (2014) state that the students who were taught through role play got better result than the students who were taught through information gap. It is caused by the strategy that is used. Role play gives the opportunity to the students to explore their ability to be more active in teaching and learning process. The students have opportunities for stimulating their speaking skills which they can perform easily in the front of the class. In other words, role play helps the students to improve their speaking skill.

Krebt (2017) found that role-play improved the performance in the Iraqi English as Foreign Language students in speaking test. Accordingly, the students under experimental group seemed to succeed because of getting involved and practice in role play technique such as group work and peer work. It can be inferred that if the class is framed as a community to work together supporting each other, it will have the opportunity to work for the same aims. This builds their ability to interact with and understand each other, the best basis for all learning. Furthermore, the results of the present study confirm that role play techniques provide a kind of interesting environment for the students to flourish in such environment leads to better attention in learning and stimulate them to participate in role-play techniques. In role play techniques, students take a new identity and learn to use a foreign language for every day interaction.

\section{Types of Role Play}

There are three types of role play, they are: fully scripted role-play, semi-scripted role-play and non-scripted role play. In a fully scripted role-play, each word is given, and each student should understand or memorize his/her role (Harper-Whalen \& Morris 2005). Such type includes explaining the model 
conversation in the prescribed textbook and the main aim of the conversation after all is to make each item of the language meaningful and easy to remember. Byrne (1986) indicates that role play in this type can be appropriate for low level students who do not know the situation in the semi-scripted role play. The second one of role play includes a model conversation with some missing words and students should know how to fill in the blanks in suitable words of these contexts (Livingstone 1983). So, students can change the main conversation to some certain way and establish their own conversation. Such type of role play might be called as semi controlled or as the teacher or prescribed textbook includes language input, but students should also specify the materials depend on a frame which supplies the situations to establish a real life context. This type can be used for students with upper-beginner to intermediate levels of proficiency, those students should be familiar with main procedures and seeks to go to higher level of tasks as semi-scripted role-play is less structured and less controlled than fully scripted role-play.

In the third type of role play where students are given with keywords of dialogues (Dickson 1989), keywords and information, or contexts and aims in less controlled and structured tasks, in this type, students establish mini conversation based on keywords mentioned above, materials or contexts are simply as filling in gaps (Pi-Chong 1990). Identifying such type of role play as non-scripted role play, and they argue that non-scripted role play provides a great chances to employ the information of techniques in a certain situations. Davies (1990) states that students can build on their opinions and thoughts, and establish language on their level, acting out in some situations based on their understanding. Non-scripted role-play can be practical to for middle to advanced level students as non-scripted role play in a free and structured way which sometimes demands special skills like problem-solving.

\section{Methodology}

This study was based on an experimental research among 40 secondary level students of grade X of a public school from Lamjung district. All the tenth grade students of the school were the participants. Out of them, 20 students were in the experiment group whereas the same number of students was in the control. The participants were grouped according to their class role number, i.e., odd in one group and even in other.

The tools for data collection were observation and speaking test. The results of the pre-test and posttest of both groups (experiment group and controlled group) were interpreted and analyzed using statistical tools such as mean, standard deviation and t-test.

The sampled population was divided into two groups having similar learning capacity. The traditional techniques were used in the controlled group whereas role play technique was used in the experimental group. Before implementing role play technique to the experimental group, the pre-test was conducted on $1^{\text {st }}$ October 2018. The pre-test was administered on the sample of the study for two groups. The researcher himself tested the sample of the study and he recorded the answers for scoring. The time needed for answering the question was between 10-15 minutes. The aim behind carrying out the pre-test is to compare the students' achievement scores in the pre-test with that of the same students in the post-test.

The speaking class met three times a week. The teacher read the conversation aloud and then pointed a couple of students to read it in front of the whole class. Then, the teacher pointed out to the students if 
they faced any difficult words or expressions in order to analyze and explain them. Students were asked to be in their assigned groups from last class during the three hours. Only given some minutes to remember and practice their conversations. Then, they were called up randomly to practice. This step conducted to encourage students; meanwhile the teacher should grade their performance on a rating scale of 1 to 20 . In addition, a peer observation is conducted by asking students to grade their colleagues in similar scale. Member of each pair were scrambled with each time of practicing a new conversation to avoid of feeing bored. Whenever the teacher had spare time (which was rare), he asked couples perform in front of the whole classmates and also practice one of the previous conversations or they can choose a subject to talk about.

At the end of the teaching period, the students of the experimental group and controlled group were post tested on $15^{\text {th }}$ November, 2018. The same testing procedures were used for pre-test and post-test of both groups. The students' oral performance in the post-test was scored under the same conditions as that of the pre-test. The time require for answering the questions was 10-15 minutes for each students. The researcher conducted the pre-test and the post-test under the same conditions.

\section{Results and Discussion}

The performance of the experimental group was observed by the researcher with the observation checklist. The researcher as the teacher decides the teaching materials, selects the situations and creates the dialogues, creates the activity that requires the students to work together to achieve a purpose. The teacher also teaches dialogue for role play, asks the students to practice the dialogue, gives the students a desire to communicate, gives the students opportunity to express personal feeling, ideas and opinion, provides supportive and dynamic classroom that make the students feel confident in using the language. The observation checklists for the students, found that the students have worked together to achieve purpose. The students felt more confidence in using the language and the students remained active in teaching and learning process.

The data were analyzed by applying the statistical methods: mean; standard deviation and t-test. The mean score of the controlled group and the experimental group is found almost same in the pre-test, i.e., 8.08 of the controlled group and 8.0 of the experimental group. On the other hand, the difference in mean score is found a bit bigger in the post-test of the control and experimental group. The mean score of the experimental group is 14.72 , while the mean score of the controlled group is 10.52 .

Finally, t-test is applied to determine whether or not the difference is statistically significant. Here, $\mathrm{t}$-calculated value of the post test is 2.28 while t-tabulated value is 2.0. T-tabulated value is found out at 0.05 level of significance. Here, $t$-calculated value is found greater than $t$-tabulated value. This indicates that there is a significant difference in the total scores of post-test between the experimental and control groups in a favor of the experimental group. This confirms that the experimental group is better than the controlled group (see table 1). 
Table 1

Total scores of the post-test

\begin{tabular}{|l|l|l|l|l|l|l|l|}
\hline Group & No. & X & SD & DF & Calculate t-value & Tabulated t-value & Level of significance \\
\hline Experimental & 25 & 14.72 & 1.90 & 48 & 2.28 & 2.0 & 0.05 \\
\cline { 1 - 4 } Controlled & 25 & 10.52 & 2.06 & & & & \\
\hline
\end{tabular}

Table 1 shows that students' accents improved with experimental group more than controlled group. It may be common fact to obtain this result because role play technique asks students to practice speaking and listening more than reading and writing. Students also should practice the repetition of the same words or expressions many times to comprehend their conversation. They were asked to focus consciously on their accent and pronunciation in particular; also they focused on memorizing each line (this could be done mentally without speaking aloud). As a result, students might have paid more attention to accent or pronunciation while speaking.

The result of the present study showed that the students who were taught through role play got better result than the students who were taught through traditional grammar based method. It is caused by the strategy that is used. Role play gives the opportunity to the students to explore their ability to be more active in teaching and learning process. The students have the opportunities for stimulating their speaking skills and they can easily perform in the front of the class. So, based on the obtained results, certain justifications concerning the effectiveness of using role play techniques on Nepali English as a Foreign Language students' speaking skill can be made.

When students were assigned a situation to role play in, they had put in the effort to think of the appropriate language that could be used to express their views and thoughts for communication. It also helped them to acquire speaking skill and oral fluency, which also helped to boost their confidence level. As speaking skill requires more 'practice and exposure', role play can play an effective role. A clear observation of the similarly assigned situation helped the students to adapt to the moods and vocal expression of the given situation, which they could then perform. For example, when they were assigned to play the roles of a salesman and a customer, they were introduced to a 'different social context' which was new, interesting, and challenging for them. It gave them an opportunity to show their creativity because the life style, language, emotion, environment, expression and body language would be different. As they took preparation for the play, it not only helped them to gain back their confidence but also helped in acquiring fluency in the target language.

Accordingly, the students under experimental group seemed to succeed because of getting involved and practice in role play technique such as group work and peer work. It can be inferred that if the class is framed as a community to work together supporting each other, it will have the opportunity to work for the same aims. This builds their ability to interact with and understand each other, the best basis for all learning. Moreover, the results of the present study confirm that role play techniques provide a kind of interesting environment for the students which lead to better attention in learning and stimulate them to participate in role-play techniques. In role-play techniques, students take a new identity and learn to use a 
FL for every day interaction.

Furthermore, students' vocabulary improved in experimental group more than control group. In role play, although as teachers gave them selected topics, they selected the words and phrases of their own, which helped them to choose suitable words that suited the situation and also helped them to increase their vocabulary.

Moreover, students in the post-tests might not find the contexts very complicated or even tried overcome these contexts. In the contrary, students were very aware of making conversation clear for themselves and their partners.

\section{Conclusion and Implications}

Based on the finding of the research it can be concluded that role play is an effective technique to develop speaking skill of the students. The result shows that the mean score of the experiment group and the controlled group in speaking skill is found 14.72 and 10.52 respectively. It can be generalized that role play technique improved the learners speaking skill. It is because the positive aspect of the role play technique in EFL classroom is it develops confidence and creativity on students as they are motivated to take part in speaking skills. The regular practice of role play makes the students fluent in English. Moreover, it develops vocabularies which help to choose suitable words that suit in the situation. Finally, the study proves that role play has an important pedagogical implication in EFL classroom to improve the communicative skills of the students in Nepali classroom.

\section{References}

Byrne, D. (1986). Teaching oral English. London: Longman.

Chaney, A. L. (1998). Teaching oral communication. In Grandes K-8. Boston: Allyn and Bacon.

Cornett, C. E. (1999). Whole language, whole learning: Phil Delte Kappa Educational Foundation.

Dickson, P. S. (1989). Acting french drama techniques in the second language classroom. The French Review, 63(2), 300-311.

Doff, A. (1992). Teach English. Cambridge: Cambridge University Press.

Harper-Whalen, S. \& Morris, S. (2005). Using a role-play activity in training. Training Solutions. 9, 1-4.

Hedge, T. (2000). Teaching and learning on the language classroom. New York: Oxford University Press.

Holt, L. C. \& Kysilka, M. (2006). Instructional patterns: Strategies for maximizing student learning. Thousand Oaks, CA: Sage.

Kenneth O. G. (2008). Teaching through role playing. Retrieved from https://bible.org/seriespage/3-teaching-throughrole-playing.

Krebt, D. M. (2017). The effectiveness of role play techniques in teaching speaking for EFL college students. Journal of Language Teaching and Research, 8(5), 863-870.

Liu, F. \& Ding, Y. (2009). Role-play in English language teaching. Asian Social Science, 5(10), 140-143. Retrieved from http://www.ccsenet.org/journal/index.php/ass/article/download/3988/35 34 .

Livingstone, C.(1983). Role play in language learning. Singapore: London: Longman.

Ments, V. M. (1999). The effective use of role-play: practical techniques for improving learning (2nd ed.). Retrieved from. html?id=GbXOYf8aTIC\&redir_esc $=\mathrm{y}$

Richards, J. (1985). Longman Dictionary of Applied Linguistics. London: Longman.

Savingnon, S.J., \& Wang, C. (2003). Communicative Language Teaching in EFL Contexts; Learner Attitude and 
Perceptions. (Electronic version). International Review of Applied Linguistics in Language Teaching, 41(3), 223-249.

Tompkins, P.K. (2001). The Role Playing and Simulation. TESOL, IV (8).

Yuliana, Y., Kristiawan, M. and Suhartie, T. (2014). The Effect of Role Play Toward Students' Speaking Skill (an Experiment Study at Grade XI IPA High School 1 Batang Anai, Padang Pariaman Regency, West Sumatera, Indonesia). The Journal of Applied Sciences Research. 1(4): 279-283.

\section{Appendix A}

\begin{tabular}{|c|c|c|c|c|c|c|c|c|c|c|c|}
\hline \multicolumn{12}{|c|}{ Marks Obtained by Control Group in Pre-test and Post -test } \\
\hline \multicolumn{6}{|c|}{ Pre-test } & \multicolumn{6}{|c|}{ Post- test } \\
\hline $\mathbf{X}$ & $\mathbf{F}$ & Ex & $\mathbf{X}-\mathbf{X}=\mathbf{X}$ & $x^{2}$ & $\mathrm{fx}^{2}$ & $\mathbf{x}$ & $f$ & $f x$ & $\mathbf{X}-\mathbf{X}=\mathrm{x}$ & $x^{2}$ & $f x^{2}$ \\
\hline 4 & 1 & 4 & -4.08 & 16.64 & 16.64 & 7 & 2 & 14 & -3.52 & 12.39 & 24.78 \\
\hline 5 & 2 & 10 & -3.08 & 9.48 & 18.96 & 8 & 2 & 16 & -2.52 & 6.35 & 12.7 \\
\hline 6 & 4 & 24 & -2.08 & 4.32 & 17.28 & 9 & 4 & 36 & -1.52 & 2.31 & 9.24 \\
\hline 7 & 3 & 21 & -1.08 & 1.16 & 3.48 & 10 & 6 & 60 & -0.52 & 0.27 & 1.62 \\
\hline 8 & 5 & 40 & -0.08 & 0.0064 & 0.03 & 11 & 3 & 33 & 0.48 & 0.23 & 0.69 \\
\hline 9 & 4 & 36 & 0.92 & 0.84 & 3.36 & 12 & 3 & 36 & 1.48 & 2.19 & 6.57 \\
\hline 10 & 2 & 20 & 1.92 & 3.68 & 7.36 & 13 & 3 & 39 & 2.48 & 6.15 & 18.45 \\
\hline 11 & 2 & 22 & 2.92 & 8.52 & 17.04 & 14 & 1 & 14 & 3.48 & 12.11 & 12.11 \\
\hline 12 & 1 & 12 & 3.92 & 15.36 & 15.36 & 15 & 1 & 15 & 4.48 & 20.07 & 20.07 \\
\hline 13 & 1 & 13 & 4.92 & 24.2 & 24.2 & & & & & & \\
\hline Total & 25 & 202 & & & 123.71 & & 25 & 263 & & & 106.23 \\
\hline \multicolumn{3}{|c|}{$\operatorname{Mean}(X)=8.08$} & & & & Mea & $X)=$ & & & & \\
\hline
\end{tabular}

\section{Appendix B}

\begin{tabular}{|c|c|c|c|c|c|c|c|c|c|c|c|}
\hline \multicolumn{12}{|c|}{ Marks Obtained by the Experimental Group in Pre-test and Post-test } \\
\hline \multicolumn{6}{|c|}{ Pre-test } & \multicolumn{6}{|c|}{ Post- test } \\
\hline $\mathrm{X}$ & $\mathrm{f}$ & $\mathrm{fx}$ & $X-X=x$ & $\mathrm{x}^{2}$ & $f x^{2}$ & $\mathrm{X}$ & $\mathrm{f}$ & $f x$ & $X-X=x$ & $x^{2}$ & $f x^{2}$ \\
\hline 4 & 1 & 4 & -4 & 16 & 16 & 10 & 1 & 10 & -4.72 & 22.27 & 22.27 \\
\hline 5 & 2 & 10 & -3 & 9 & 18 & 12 & 5 & 60 & -2.72 & 7.39 & 36.95 \\
\hline 6 & 4 & 24 & -2 & 4 & 16 & 13 & 1 & 13 & -1.72 & 2.95 & 2.95 \\
\hline 7 & 3 & 21 & -1 & 1 & 3 & 15 & 5 & 75 & 0.28 & 0.07 & 0.35 \\
\hline 8 & 6 & 48 & 0 & 0 & 0 & 16 & 11 & 176 & 1.28 & 1.63 & 17.93 \\
\hline 9 & 3 & 27 & 1 & 1 & 3 & 17 & 2 & 34 & 2.28 & 5.19 & 10.38 \\
\hline 10 & 3 & 30 & 2 & 4 & 12 & & & 368 & & & 90.83 \\
\hline 11 & 1 & 11 & 3 & 9 & 9 & & & & & & \\
\hline 12 & 1 & 12 & 4 & 16 & 16 & & & & & & \\
\hline \multirow[t]{2}{*}{13} & 1 & 13 & 5 & 25 & 25 & & & & & & \\
\hline & 25 & 200 & & & 118 & & 25 & 368 & & & \\
\hline \multicolumn{4}{|c|}{ Mean $(X)=8.0$} & & & \multicolumn{3}{|c|}{$X=14.72$} & & & \\
\hline
\end{tabular}

Binod Neupane works at Marsyangdi Multiple Campus, Besishahar Lamjung/ English Language Department and Janabikas Secondary School, Lamjung. He earned M.Ed. in English in 2003 and M.A. in Sociology in 2007 from Tribhuvan University. He works as the head of English in both institutions. He is also the chair of NELTA Lamjung, life member of NELTA and member of IATEFL. He has been teaching English Language Teaching, Foundations of Language and Linguistics, and Research Methodology in English Education since a decade. His field of interest is Applied Linguistic and Research Methodology. Mr. Neupane is now an ELT trainer of DEO Lamjung and NELTA Lamjung. 